\title{
VI.-THE MICROSTRUCTURE OF COAL FROM AN INDUSTRIAL STANUPOINT.
}

\author{
By A. L. Bоотн, A.I.C. \\ (Messrs. Armstrong, Whitworth \& Co., Ltd.).
}

(Read February 15, 1922.)

Two Plates.

Ir is now almost one hundred years since the microscope was first used to examine thin sections of coal. Early papers show that Witham used the microscupe for this purpose in 1832 to 1833 , and that he was closely followed by Hutton and Lindley. Quite an appreciable number of papers dealing with the microscopy of coal were published in this country and abroad, during the succeeding forty or fifty years. Then followed a period when interest in the matter lay dormant, but during the last twenty years a revival has taken place, and a very promising field of work seems to be opening up. Stopes and Wheeler, at the end of a "Monograph on the Constitution of Coal," published in 1918, give an excellent bibliography of the published work from 1832 to date.

Most of this work deals, however, with the constituents of the coal substance, or with theoretical considerations which attempt to account for the formation of coal ; but as yet, little work appears to have been done on the use of the microscope in fuel selection from an industrial point of view.

The worker in an industrial laboratory has two important considerations to keep always in mind. First, the works must be kept running. (This applies generally, but with particular force to a fuel laboratory.) Secondly, the works must be run as economically as possible, and no matter how empirical or comparative the methods of work may be, if they help towards better and more economical working they justify themselves.

This applies in the case of ordinary chemical analysis of coal, and it may even be said of the use of the microscope in metallography. But though ordinary chemical analysis as applied to coal may justify itself, I would like first of all to point out its limitations-why it so often fails to give essential informationand then to show you the part the microscope can play in fuel selection.

The usual method of examining coal is to make a "proximate analysis." It has to be carried out under standardized conditions 
of temperature, and with a standardized type of apparatus, to be at all comparative. The analysis usually consists of the determination of moisture, and on the dried sample, of the ash, the volatile matter and sulphur; a standardized coking test may also be made. The. proximate analysis does not give very much information unless the type of coal is known, even when carried out under these conditions, due allowance being made for the varying ash content. A standardized coking test, too, is of doubtful value when the ash content is at all high, because a high ash content tends to destroy or modify the coking power.

The "ultimate analysis" of coal-that is, the determination of the percentage of carbon, hydrogen, oxycren, nitrogen and sulphuron the other liand, has a fair degree of accuracy as its justification, and the results have been extensively used for chemical classifications. For this purpose the ratio between the carbon and hydrogen percentages is generally used. Ultimate analysis, however, is very limited in its application.

I have come to this conclusion, not only from the resuits of experience, but by reasoning from our present-day knowledge of coal ; for it is not so much in accordance with their ultimate composition that coals vary, but according to the proportion and type of substance present in the coal conglomerate. The coal conglomerate is composed of plant remains. The plauts then, as now, were mainly composed of cellulose, with ligno-cellulose, cutoses, and some resins and protein matter. Plant tissues in general are, chemically, very much alike; variations in a species, or in the different parts of the same plant, being due mainly to various polymerizations and condensations, etc., of the carbohydrates, so that the ultimate composition of the bulk of plants will be very similar. Admitting that this is so, and assuming that, in the case of coal, decomposition was fairly uniform, a coal would have to be composed, mainly, of some substance which differs markedly from the bulk of the plant remains to show any marked difference in its ultimate analysis. The hard or cannel coals are a case in point. During coal formation, however, the degree of decomposition undergone by the coal substance would

\section{EXPLANATION OF PLATE VI.}

Numbers.

$1 \& 2$.-Typical humic coal $\times 75$. Sections cut parallel with and at right angles to the bedding plane respectively.

$3 \& 4$.- Spore coal showing spore exines $\times 20$. Parallel with and at right angles to the bedding plane respectively.

$5 \& 6$.- Hard or cannel coal showing the small round "yellow bodies" $\times 170$. Parallel with and at right angles to the bedding plane respectively.

$7 \& 8$.-A good steam-raising coal. Mainly humic, but containing much cuticle and spore exines. No. $7 \times 20$ (parallel with bedding plane). No. 8 $\times 170$ (at right angles). 


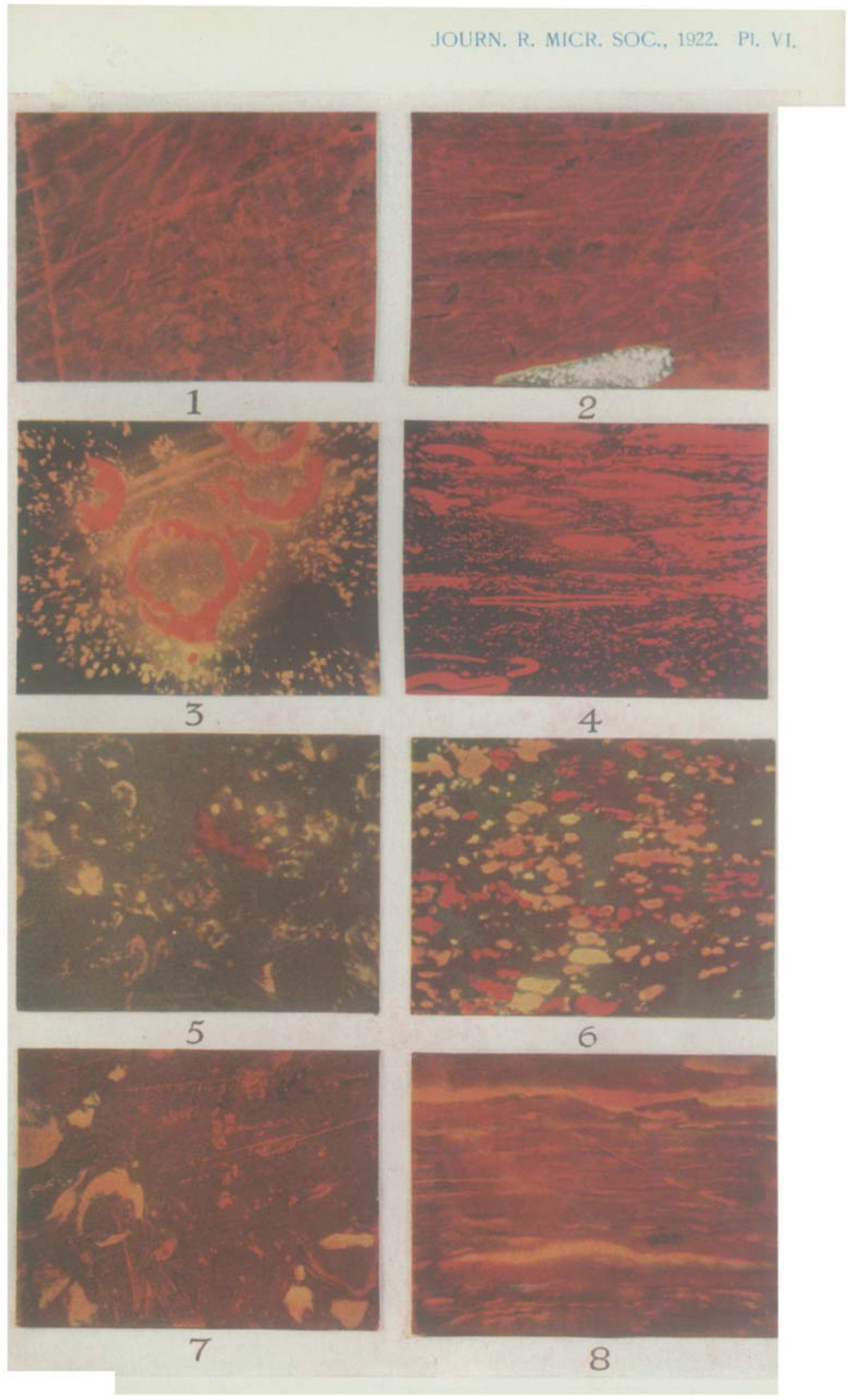


not be uniform. Some portions would undergo fairly rapid decay, while others would be covered and protected from bacterial and other actions, so that we might expect to find plant remains which are but slightly altered. These remains might, perhaps, be broken up, but not necessarily much altered in composition. 'The microscope, in fact, shows but slightly altered plant tissues, and various workers seem to agree that it is possible to dissolve out small amounts of cellulose from some coals. Cellulose contains a high proportion of oxygen and hydrogen in its molecule; and a small proportion of only slightly altered cellulose tissue in a coal will have a very marked influence on the ultimate analysis. It follows, then, that two coals which are composed of similar vegetable remains, may have very different ultimate compositions, without being very dissimilar in their general properties. In practire this is found to be so. I would repeat, it is not so much in accordance with the carbon, hydrogen and oxygen content that coals vary, but rather with the proportion and type of the different substances in the coal conglomerate. Chemical classifications do not take these points into consideration, and by chemical analysis, so far, it has not been possible to identify satisfactorily the various coal substances.

By far the greater part of the coal found in this country is classified by the usual chemical methods as "bituminous." The chief exceptions are the anthracitic coals of South Wales. It is with these so-called " bituminous" coals only that I intend to deal ; so far as I am aware no really satisfactory sections of the anthracitic coals have been prepared. The "bituminons" coals are of great industrial importance, and consequently numerous attempts have been made to group them according to their behaviour when in use. It is obvious to even the most casual observer that there are great differences in coals when burnt, say, in an open grate. Some are fragile and ignite readily; others are very hard and difficult to ignite; some swell up and coke; while others burn away to ash withont any formation of coke. Some coals burn with a long flame, others with a short one. Hence we get such terms as "dry coals," "fat coals," "lean coals," "long and short flaming coals," etc. Bone, in his book on "Coal and its Scientific Use," gives a modification of the Regnault Grüner classification (which is one of the earliest, and is based on the oxygen-carbon ratio of the coal-a most unsatisfactory method). The "bituminous" coals are divided into non-coking long flame, coking long, flame, hard coking, and hard coking short flame.

Bone remarks, "The author's own investirations on typical English coals have brought to light some interesting examples of coals possessing quite different properties whose elementary compositions are very similar."

I have examined over two hundred different coals in the last 
few years, during which time hundreds of analyses have been made, and $I$ can say that this similarity occurs fairly frequently. From considerations already stated, it is obvious that this must be the case. It is, in fact, the converse of similar coals having different analyses.

These groupings are useful, and would be more so, were it not for the fact that the sharp distinctions of such elassifications are not met with. In nature there is a gradual transition from one type to another. It is because of constantly recurring diffisulties of this nature that the microscope was first brought into use in the hope that a better understanding in fuel selection might be reached.

The micro-structure was first applied to the selection of coal for a large twenty-two unit recovery gas plant, gasifying some 2,500 tons of coal per week, with the production of some $350,000,000$ cubic feet of gas. In this plant, worked on the Mond principle, superheated steam and air are blown through a deep fuel bed. Excess of steam is used, and so the temperature of the producer is low, the out-going gases not being above $500^{\circ} \mathrm{C}$. 'The coal is therefore subjected to a primary comparatively low-temperature distillation, and much of the "resinic" portion, which causes coking, is distilled off. It is possible in this type of plant to gasify practically any class of coal. A strongly coking slack, however, would necessitate a very slow rate of gasification and a large excess of steam, probably as much as two aud a half tons per ton of coal, so that it would not be a commercial proposition to use such a coal. In practice as high a rate of gasification with as low a steam consumption as possible consistent with good gas and a high ammonia yield is aimed for. The producer is then running economically. Careful selection of fuel goes a long way towards obtaining efficiency and the satisfactory running of such a plant. The coals used are between the coking and non-coking types, and are consequently difficult to select ordinarily. Two coals may look alike, and give practically the same results in the laboratory, but when put into use one of them may be quite satisfactory and the other unsatisfactory. I give below the analyses of two such coals; one was used successfully in the recovery plant already mentioned, but the other could not be used economically :-

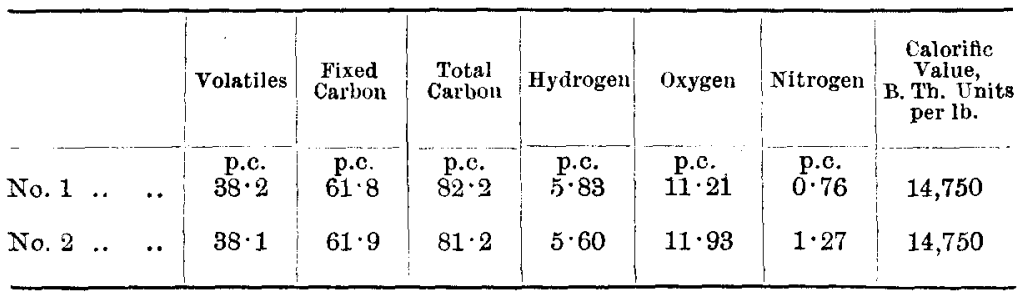


The results are calculated on the dry, ash, and sulphur-free coals; the volatile matter is the loss on heating to $950^{\circ} \mathrm{C}$. in a closed erucible surrounded by a larger crucible containing charcoal. The calorific value is by bomb determination.

The use of the microscope is comparative. Typical samples of coal which had been proved to be satisfactory, and others which were not satisfactory, were taken. Sections were cut in three directions and very carefully examined under the microscope. Photographs were taken, tinted to correspond to the actual sections, and the various coals compared. It was thought reasonable to expect that coals with a similar appearance under the microscope would behave similarly in practice. This was borne out in the works. It will be seen that it is a matter of experience and comparison upon which the method of use depends, and that it is not necessary to take into consideration the nature of the constituents of the coal for selection purposes, though one does so as a matter of interest. It is this comparative treatment which makes the method so empirical. Similar work was carried out with other classes of coal such as that used for non-recovery producers, steam boilers, direct-fired furnaces, coke manufacture, town's gas manufacture, etc.

It is quite possible by microscopic examination to pick out coals suitable for these purposes. It is usual to leave the final selection until a test has been run under working conditions, and in the running of such a practical test it is a great gain to know that unsuitable coals have been eliminated. With the ordinary methods of examination one can never feel certain, until a large scale trial has been run, that the fuel selected is the right one. Large scale trials are expensive, and if the coal is not a suitable one may have serious results.

From the study of industrial coal in general use, one is lead to the conclusion that it is possible to divide the so-called "bituminous" coals into three main classes.

One type is composed mainly of wood tissue. I use wood here in the strict sense, and not as it is generally used to denote timber. These are the soft humic coals which swell considerably on heating and form a very porous coke.

The second type has a predominance of spore coats and microspores. This class of coal is practically non-coking, a property which is to be expected when the main bulk of the coal is composed of spore exines. The "resinous" constituent of the humic coals which causes them to coke is most probably derived from the wood cell contents. This constituent is soluble in pyridine and chloroform, but the spore coals yield very little soluble matter on treatment with pyridine.

The third type consists of the hard coals or cannels. These are the non-coking long-flame coals, which are dull and compact. 
A good specimen of this class is composed almost completely of the small round bodies about which, as yet, no definite opinion seems to have been formed. If the coal section is thin enough, the small round bodies are a bright yellow with a black centre. These black centres are most probably holes which have been filled in with carbonized material. Such a coal is quite noncoking, the residue being pulverulent. In thicker sections the small round bodies become more orange-coloured. Lomax, in one of his earliest papers (Lomax: "The Microscopical Examination of Coal," etc., Trans. Inst. of Mining Engineers, Vol. 42), states that the microspores form the bulk of cannels. This statement is of interest to me, beause from examination of these bodies in other types of coal, I lean to the opinion that they are a variety of spore.

Of course, these classes are not sharp and distinct, but run into one another. There are humic coals which contain more and more spores; some coals are mostly spore, while others become cannellized as the yellow bodies merge with the spores. Some cannels contain many megaspore fragments, but others, as already stated, are almost wholly composed of yellow bodies. Cutiche from leaves and twigs, ete., is a constituent common to all types, but is more common in the humic to spore types.

Lomax, after studying a number of coal seams and cutting numerous sections, which when joined together made a thin slice of the coal, practically from floor to roof, comes to the following conclusions. That, in general, coal seams are composed as follows: First, there are the remains of ferns and horsetails; then come the Gymnosperms containing many cordiate leaves; the remains of the Lycopodiecia follow, forming the bulk of the coal. The spores from these trees become more and more numerous the higher up the seam one gets, microspores often occurring first. Cannels are found next, and then towards the top there is often a return to the remains of Gymnosperms and horsetails. (Lomax: "The Formation of Coal Seams," I.I.M.E., Vol. 50).

This arrangement will account for the three types of coal found, and the gradual transition from one type to another.

\footnotetext{
EXPLANATION OF PLATE VII.

Numbers. facture and bouse coal.

11.-Humic coal with very fine structure $\times 50$. Suitable for coking. Right angles to bedding plane.

$12 \& 13$.-Spore coals, suitable for producer gas working, $\times 25$. Parallel with and at right angles to the bedding plane respectively.

14. - Similar coal to above, but more cannellized, $\times 15$. Parallel with bedding plane.

15 \& 16.-Hard coal almost completely " cannellized" $\times 50$. The round bodies are orange-coloured, due to the section being somewhat thick. Parallel with and at right angles to the bedding plane respectively.
} 


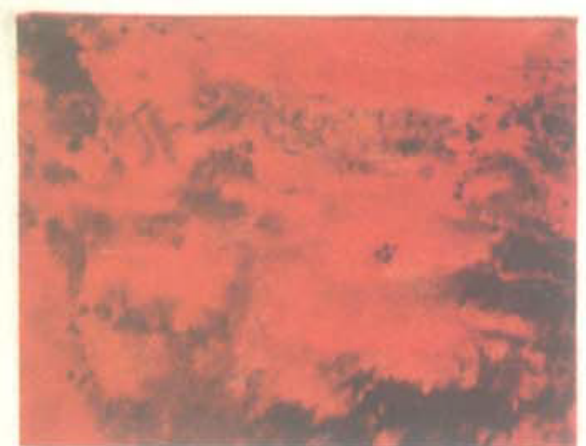

9

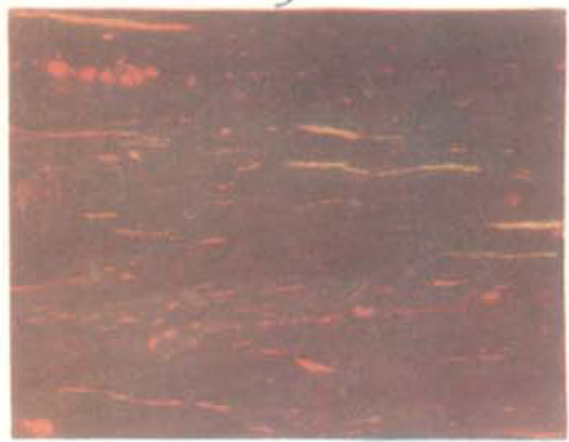

11

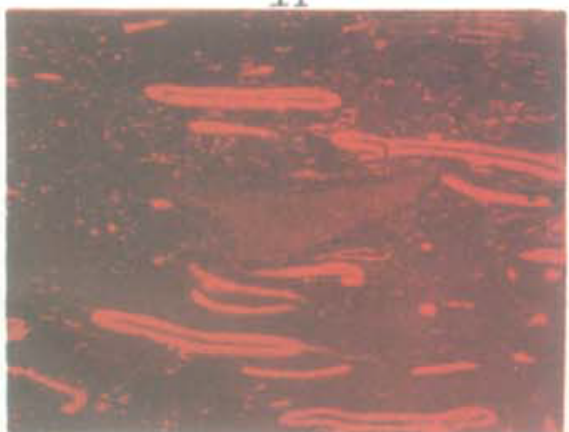

13

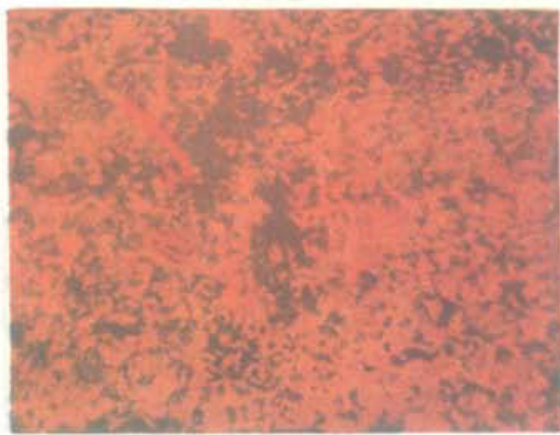

15

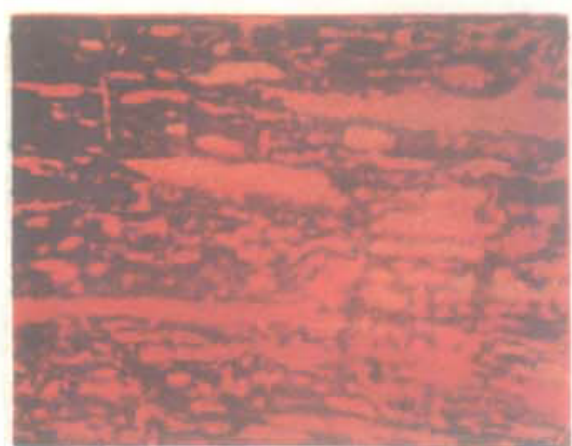

10

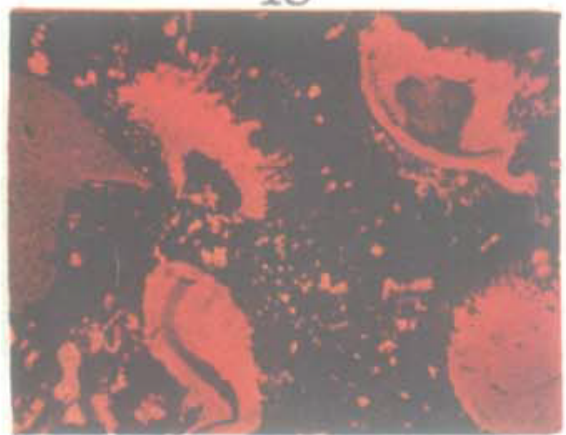

12

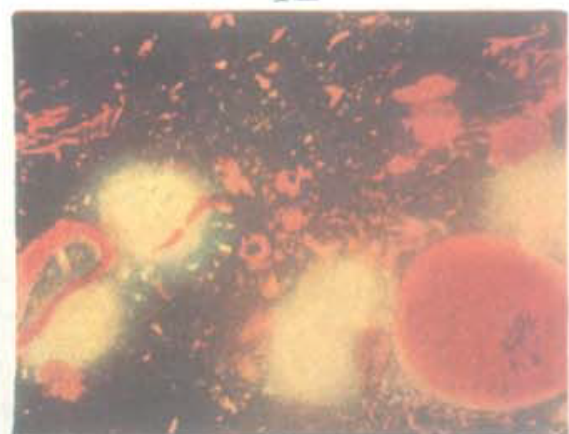

14

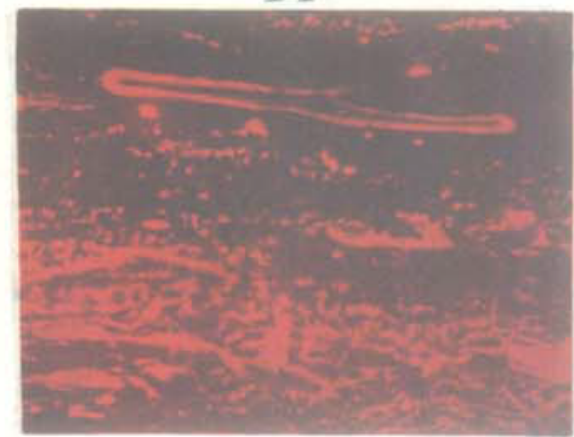

16 
It is an easy matter to distinguish between the soft humic coals and the hard cannel coals. The soft humic coal has a bright banded appearance, and it is divided by numerous cracks, mainly at right angles, which cause the coal to break into cubes. The hard cannel coal has a uniformly dull appearance, has few cracks, and is rather difficult to break. However, withont the help of the microscope it is almost impossible to distinguish by their appearance the coals containing spores in a humic ground mass and those containing spores in a cannellized ground mass, particularly when the coals are in small pieces. Yet these are the coals which are of such vital importance to industry, particularly the iron and steel industry, for amongst them occur the true coking coals, the coals which are practically non-coking, and some excellent steam coals. The true coking coals are necessary for blast furuace coke manufacture, while the practically non-coking are essential for producer gas manufacture. Steam coals are, as yet, necessary to most inclustries. The necessity for using the best available means of identifying the various classes of coal will be apparent, and in view of the fact that our coal reserves are not unlimited, it is wasteful to use a coal for one class ol work when it is more suitable for another.

In a short paper before the Iron and Steel Institute I dealt with the various uses to which these coals should be put. (Booth: "Feonomic Selection of Coal," Journal of the Iron and Steel Institute, No. 2, Vol. CII.)

The value of microscopical work in connexion with coal selection was demonstrated very clearly during the late war at the works of Messrs. Armstrong, Whitworth, Openshaw, the firm with whom I an associated. No doubt all of you will be aware that restrictions were placed upon long-distance transpurt of coal, and supplies could only be secured within a certain area. Neither could the usual sources within that area meet the increased demand, besides which usual supplies were sometimes curtailed owing to the Government having prior claims. As a consequence new sources of supply had to be tapped. Of these coals there was no previous experience, and careful selection was necessary, yet very many of them were rejected on microscopical evidence alone, little or no chemical analysis being done, and no large scale tests run. This was a great saving of time to the laboratory staff. Though there were many anxious times due to traftic delays, etc., at no time was there any inconvenience caused by the fuel department being unable to supply suitable types of coal to meet the various requirements of the works. If deliveries of a certain class of coal were temporarily stopped, it was possible, because of the more detailed knowledge gained from the microscopic work, to supply a similar class of coal or else the nearest type available. This knowledge made it possible to put into immediate effect any 
alterations in the running conditions of the particular plant made necessary by the use of a different coal, and to issue instructions beforehand for any change in the working of the coal. This eliminated difficulties which would otherwise have arisen. Had the type of coal not been known any adverse effects could only have been combated as they arose. In some cases this would have meant delays for twelve to twenty-four hours after the coal had been put on. It might even have meant partial stoppage and a consequent drop in production, etc. So far I have attempted to show you something of the selection and allocation work of a fuel department in a large industrial works, where many classes of coal are in use for a variety of purposes. I have described for you these coals and the uses to which they should be put. I have also shown you how successful fuel selection can be made when a knowledge of the microstructure of the coal is used to supplement the information given by chemical analysis. I hope I have been able to convey to you some idea of the value of the microscope for this work when in the hands of an experienced technologist. I would now like to point out to you other uses to which the microscope can be put which are of considerable interest to industry. Of special interest commercially is the identification of the various coal constituents. Little is known as yet of the influence of varying amounts of the different constituents in a coal. I have briefly referred to the nature of some constituents, but it is more in regard to the nature of the resulting bye-products from coal-distillation that the microscopic study would be helpful. This question of bye-products has been studied extensively from the chemical side, which study tends to show that temperature plays a most important part in the nature of the bye-products. Two recent examples of chemical work might be quoted. Pictét and his co-workers have published some very suggestive work on the distillation of coal in vacuo. They show that the coal substance breaks down with the formation of alcohols and the cyclic paraffins, and that the more valuable aromatic compoundsnamely, benzene homologues - are formed from these at a higher temperature (Pictét: Rev. Gen. des Sec., Oct. 1916, Vol. XXVII.)

The control of temperature is of great importance in coke manufacture. S. Roy Illingworth (J. Soc. Chem. Ind. Trans., Vol. XXXIX., Nos. 9 and 10) shows that it is possible to make a metallurgical coke from an apparently unsuitable coal by controlling the temperature. He also shows that it is varying amounts and differences in the coal constituents which cause changes in the behaviour of a coal. It will be realized that this kind of work is of great importance, but it gives no idea of the reasons why coals should vary to such an extent. It is in this connexion that I think a detailed microscopic study is vitally necessary. There is 
now a vast accumulation of knowledge on the behaviour of coals under very diverse conditions of treatment, but strictly speaking the results are only applicable to those coals upon which the results were obtained. It is usual for the various workers to give a chemical analysis of the coal upon which they have worked; some give an ultimate analysis, others a proximate, though they often give it without any particulars as to the conditions of the analysis. As already pointed out these chernical analyses may be entirely misleading. If a description and illustration of the microstructure of the coal had been included as a matter of course, the value of this accumulated knowledge would be enormously enhanced. In all probability it would be possible from a study of the matter published to draw conclusions in regard to the influence of the coal constituents on the properties. Further means of verification and study would have suggested themselves. As it is the greater part of the published works lack the essential common factor whereby the whole can be correlated. A great step forward will have been made when workers on coal include a microanalysis in their results. Had such a course been followed in the past many misleadiug statements would never have been made. Various workers. for instance, have implied that the spore exines were resinous. It is now known that the "resinous" matter in coal is the cause of coking, and that after treatment with pyridine, in which the "resinous" maiter is soluble, coals lose their coking properties; yet spore exines are found in the insoluble portion of the coal. Again, coals in which spore exines predominate are practically non-coking.

This microscopical study of coal constituents is essentially the work of the trained palæobotanist. Stopes and Wheeler in their previously mentioned monograph summarize the possibilities in this direction, and describe many of the chief constituents of the coal substance. But before much can be said about the coal constituents methods will have to be devised for separating the chief ones and studying their behaviour under various conditions. The chemist must work side by side with the palæobotanist and their results correlated. Real progress can only be made by combining the work of the two.

The micrustructure of coal can give most valuable information, not only to the fuel technologist and palæobotanist, but also to the geologist. The Geological Survey and the Fuel Research Board are co-operating in a survey of the British coal seams. It is to be hoped that a detailed account of the microstructure of the whole thickness of the seams will be included in their report. Such a survey is long overdue. From a national point of view it will supply most essential information as to the available resources of the various classes of coal. The coal owners and users would undoubtedly benefit by such a survey. Since the 
coal resources of the country are in private hands the collieries themselves should contribute to the expense incurred.

The demand for coal has generally been equal to, or in excess of, the quantity raised, otherwise one would have expected the more enterprising colliery companies to have had made a detailed examination of their seams. One or two such surveys have been attempted but never completed. Such an examination would enable the collieries to state the types of coal they could supply. Much valuable hard coal is wasted through being mixed with softer varieties, considerable inconvenience being experienced. Black smoke from boilers can often be traced to the presence of hard cannel coal in the fuel used. Much of our present smoke trouble could be minimised if more attention were given to the securing of unmixed supplies of fuel. The micro-examination of a mixed seam, from floor to roof, would tell whether there was a sufficiency of one type of coal to justify separate working.

Though the use of mixed types of coal is to be deprecated when the mixtures are an unknown quantity, a good hard coal can be made to carry a proportion of a softer coal without detriment to its characteristic properties, if carefully and judiciously mixed. Some coling coals will also carry a proportion of a coal of inferior coking properties, or if a good spore coal is used in recovery gas practice a proportion of humic coal can be carrierl. The high nitrogen content of the latter will increase the ammonia yield.

If the collieries were able to state their types of coal, a purchaser could choose the type most suitable for his needs, or have definite mixtures made. He would require very little other information. 